\title{
A longitudinal cohort study on quality of life in stroke patients and their partners: Restore4Stroke Cohort
}

Citation for published version (APA):

van Mierlo, M. L., van Heugten, C. M., Post, M. W. M., Lindeman, E., de Kort, P. L. M., \& Visser-Meily, J. M. A. (2014). A longitudinal cohort study on quality of life in stroke patients and their partners: Restore4Stroke Cohort. International journal of stroke, 9(1), 148-154. https://doi.org/10.1111/j.17474949.2012.00882.x

Document status and date:

Published: 01/01/2014

DOI:

10.1111/j.1747-4949.2012.00882.x

Document Version:

Publisher's PDF, also known as Version of record

Document license:

Taverne

Please check the document version of this publication:

- A submitted manuscript is the version of the article upon submission and before peer-review. There can be important differences between the submitted version and the official published version of record.

People interested in the research are advised to contact the author for the final version of the publication, or visit the DOI to the publisher's website.

- The final author version and the galley proof are versions of the publication after peer review.

- The final published version features the final layout of the paper including the volume, issue and page numbers.

Link to publication

\footnotetext{
General rights rights.

- You may freely distribute the URL identifying the publication in the public portal. please follow below link for the End User Agreement:

www.umlib.nl/taverne-license

Take down policy

If you believe that this document breaches copyright please contact us at:

repository@maastrichtuniversity.nl

providing details and we will investigate your claim.
}

Copyright and moral rights for the publications made accessible in the public portal are retained by the authors and/or other copyright owners and it is a condition of accessing publications that users recognise and abide by the legal requirements associated with these

- Users may download and print one copy of any publication from the public portal for the purpose of private study or research.

- You may not further distribute the material or use it for any profit-making activity or commercial gain

If the publication is distributed under the terms of Article $25 \mathrm{fa}$ of the Dutch Copyright Act, indicated by the "Taverne" license above, 


\title{
A longitudinal cohort study on quality of life in stroke patients and their partners: Restore4Stroke Cohort
}

\author{
Maria L. van Mierlo ${ }^{1}$, Caroline M. van Heugten²,3, Marcel W. M. Post ${ }^{1}$, \\ Eline Lindeman, Paul L. M. de Kort', and Johanna M.A. Visser-Meily
}

Background Stroke is a major cause of disability in the Western world. Its long-term consequences have a negative impact on the quality of life of both the patients and their partners.

Aim The aim of the Restore4Stroke Cohort study is to investigate the changes in quality of life of stroke patients and their partners over time, and to determine factors predicting quality of life in several domains, especially personal and environmental factors.

Method Multicentre prospective longitudinal cohort study. Inclusion and the first assessment take place during hospital stay in the first week post-stroke. Follow-up assessments take place at two months, six months, one year, and two years post-stroke. Recruitment of $\mathbf{5 0 0}$ patients from stroke units in six participation hospitals is foreseen. If the patient has a partner, he or she is also asked to participate in the study.

Outcomes The main outcome is quality of life, considered from a health-related quality of life and domain-specific quality of life perspective. Factors predicting long-term quality of life will be determined by taking into account the health condition (pre-stroke health condition and strokerelated health condition), personal factors (e.g. coping and illness cognitions), and environmental factors (e.g. caregiver burden and social support).

Discussion This study is expected to provide information about the changes in quality of life of stroke patients and their partners over time. Furthermore, the identification of factors predicting quality of life can be used to improve

Correspondence: Johanna M.A. Visser-Meily, University Medical Center Utrecht, Department of Rehabilitation and Sports Medicine, PO Box 85500, 3508 GA Utrecht, The Netherlands.

E-mail: j.m.a.visser-meily@umcutrecht.nl

${ }^{1}$ Rudolf Magnus Institute of Neuroscience and Center of Excellence for Rehabilitation Medicine, University Medical Center Utrecht and Rehabilitation Center De Hoogstraat, Utrecht, The Netherlands ${ }^{2}$ School for Mental Health and Neuroscience, Maastricht University, Maastricht, The Netherlands

${ }^{3}$ Department of Neuropsychology and Psychopharmacology, Maastricht University, Maastricht, The Netherlands

${ }^{4}$ Department of Neurology, St. Elisabeth hospital, Tilburg, The Netherlands

Conflict of interest: None declared.

DOI: $10.1111 / j .1747-4949.2012 .00882 . x$ rehabilitation care and develop new interventions for stroke patients and their partners.

Key words: longitudinal cohort, personal factors, quality of life, stroke

\section{Introduction}

In the Netherlands between 34000 and 41000 persons suffer a stroke each year (1), making stroke one of the most common causes of disability in adults (2). A stroke significantly influences the patient's physical, social, and psychological functioning (3). Traditionally, much research and rehabilitation care has focused on the physical and functional impact of a stroke (3-5). Recently, the impact of stroke on concepts like quality of life (QoL) has received more attention in the stroke literature (6).

Post-stroke survival rates have been raised due to major improvements in acute stroke care, such as the implementation of stroke units and the use of thrombolysis. As a result, more people have to cope with the consequences of stroke $(7,8)$, experiencing long-term difficulties in terms of QoL $(5,9)$, social reintegration (7), life satisfaction (10), and emotional functioning, including depression and anxiety (11).

The patients themselves are not the only ones experiencing negative consequences after their stroke. After discharge from hospital, most stroke patients return to their own homes with or without rehabilitation treatment (12). Home care is mostly provided by the partners. Taking care of a stroke patient can lead to high levels of caregiver burden in terms of feelings of responsibility, constant anxiety, decreased social activities, and feelings of loneliness (13-20).

Results of earlier studies show that not only the consequences of the stroke (e.g. physical and cognitive) influence long-term QoL of stroke patients and their partners. Personal factors (e.g. passive coping) $(21,22)$ and environmental factors (e.g. social support and family functioning) $(6,23)$, defined according to the International Classification of Functioning (ICF) (24), also have a large impact on QoL.

Until now, not much attention has been paid in the stroke literature to the changes in QoL of stroke patients and their partners over time and the influence of personal and environmental factors on QoL. Additionally, sample sizes in previous studies have often been small $(3,6,9)$. With a new rehabilitation research programme, called Restore4Stroke, we want 
to overcome these shortcomings. Restore4Stroke aims to improve the QoL of stroke patients and their partner. This will be accomplished through four projects; the present Restore4Stroke Cohort study, two randomized controlled trials (RCTs), and an economic evaluation study. The first RCT focuses on reducing depression and anxiety complaints in stroke patients (Restore4Stroke augmented Cognitive Behavioural Therapy), while the second RCT is aimed at enhancing self-management in stroke patients and their partners (Restore4Stroke Self-Management). In addition, an economic evaluation study ( $€$-Restore4Stroke) considers the economic aspects of stroke and the two interventions. The designs of these other three studies are submitted for publication elsewhere. In this paper, we present the study design of the Restore4Stroke Cohort study, which started in March 2011.

The aims of the Restore4Stroke Cohort study are (1) to investigate QoL over a two year period post-stroke in both stroke patients and their partners, and (2) to determine associations between health condition factors, personal factors, and environmental factors with QoL.

\section{Methods}

\section{Design}

The present study is a multicentre prospective longitudinal cohort study in which participants are followed using five assessments during the first two years from stroke onset.

\section{Patient population}

A total of 500 patients are being recruited from stroke units in six participating hospitals in the Netherlands. If the patient has a partner, he or she is also asked to participate in the study.

It is expected that $40 \%$ of the stroke patients will drop out during the two year follow-up period due to various reasons (recurrent stroke, comorbidity, refusal, death). Inclusion of 500 stroke patients is therefore expected to lead to a total of 300 stroke patients being available to analyse determinants of long-term consequences. A total of 300 stroke patients will allow estimation of the prevalence of a certain consequence with satisfactory precision, for example a prevalence of $20 \%$ with a $95 \%$ confidence interval of $\pm 4.6 \%$ (alpha $=0.05$; power $=0 \cdot 80$ ). To analyse the associations with QoL over time, a total of 300 stroke patients will allow regression models with 15 determinants and 15 to 20 subjects per determinant.

We expect to include approximately 300 partners. This estimate is based on earlier research in which $68 \%$ of the stroke patients in a rehabilitation centre had a partner (25). The inclusion period for each hospital is one year. As each of the six hospitals has a turnover of approximately 400 stroke patients a year, the inclusion of 500 stroke patients appears feasible.

\section{Inclusion and exclusion criteria}

Stroke patients are eligible for this study if they have a clinically confirmed diagnosis of stroke (ischaemic or intracerebral haemorrhagic lesion) and have suffered their stroke within the last seven days. Partners of the participating stroke patients must be married to the stroke patients or be in a steady relationship with them. All participants must be at least 18 years old.

Participants (stroke patients and their partners) are excluded if they (1) have a serious other condition whereby an interference with the study outcomes is expected (e.g. neuromuscular disease); (2) were already dependent regarding activities of daily living before their stroke as defined by a Barthel Index score of 17 or lower (26); or (3) have insufficient command of the Dutch language to understand and complete the questionnaires (based on clinical judgment). Furthermore, stroke patients are excluded if they were already suffering from cognitive decline as defined by a score of 1 or higher on the Heteroanamnesis List Cognition, before their stroke (27).

Post-stroke aphasia is not an exclusion criterion. If this problem renders patients incapable of filling in questionnaires during the follow-up assessments, only the observational measures are conducted. The ability to fill in questionnaires is evaluated by using the Stichting Afasie Nederland - Scale (28) at each assessment: if aphasia is considered on the basis of item 9 on the National Institutes of Health Stroke Scale (NIHSS) (score $>0$ )(29), the Stichting Afasie Nederland - Scale is used to discriminate whether only observational measures are conducted (score 0 to 4 ) or observational measures and questionnaires are conducted (score 5 to 7 ).

\section{Procedure}

All participants (stroke patients and partners) are informed of the nature of the study by a nurse practitioner or trial nurse. After informed consent is given, a nurse practitioner or trial nurse conducts the first assessment (T1) during hospital stay in the first week post-stroke.

The follow-up assessments take place at two months (T2), six months (T3), one year (T4), and two years (T5) poststroke. As the assessments of the stroke patients at T2 and T3 involve observational measures, a research assistant visits the stroke patient at home or at the institution where the patient is residing at that moment. In order to spread the burden for the participants, the outcome questionnaires are sent in advance, after the appointment for T2 and T3 is made. The observational measures and remaining questionnaires are completed during the visit.

At T3, T4, and T5, patients and their partners can decide if they want to complete the questionnaires on paper or online. Previous research has found no differences between electronically processed questionnaires and questionnaires administered on paper (30). 


\section{Measures}

The main outcome is QoL, which is considered both from a general health-related QoL (HRQoL) and a domain-specific QoL perspective. The general HRQoL perspective is operationalized as disease-specific HRQoL and generic HRQoL. The domain-specific perspective consists of the domains of participation, emotional functioning, and subjective wellbeing. An overview of this operationalization is shown in Fig. 1.

An overview of all measurement instruments that are administered during the two year follow-up is shown in Table 1 (stroke patient) and Table 2 (partner).

\section{Outcome}

Disease-specific HRQoL is measured with the short version of the Stroke-Specific Quality of Life Scale (31). This instrument measures the impact of stroke on HRQoL and on two, physical and psychosocial, HRQoL domains. Each domain consists of six items. Psychometric properties of both the subscales and the total scale are sufficient (31).

Generic HRQoL is measured with the Six-Dimensional EuroQoL (32), which comprises six items: mobility, self-care, usual activities, pain/discomfort, anxiety/depression, and cognition. Each item is scored on a three-point scale, ranging from 'no problems' to 'extreme problems'. The Six-Dimensional EuroQoL has shown good psychometric properties (32).

Participation is assessed with the Utrecht Scale for Evaluation of Clinical Rehabilitation - Participation (33), which consists of 32 items in three scales, representing the frequency of social activities (11 items), experienced participation restrictions (11 items), and satisfaction with participation (10 items). The Utrecht Scale for Evaluation of Clinical Rehabilitation - Participation was shown to be a valid and reliable measure to rate participation in patients with various physical disabilities, including stroke patients $(49,50)$.

Emotional functioning is measured with the Hospital Anxiety and Depression Scale (34), consisting of 14 items measuring both anxiety and depression with seven items each. The Hospital Anxiety and Depression Scale has shown good psychometric properties (34), and is a commonly used measure in stroke patients (51).

Subjective well-being is measured with a brief life satisfaction measure consisting of three items. The first two items measure current and pre-stroke life satisfaction, respectively, and are scored on a six-point scale, ranging from 1 (very dissatisfied) to 6 (very satisfied). The third item asks the participants to compare their current life satisfaction with the pre-stroke situation, a seven-point scale ranging from 1 (much worse) to 7 (much better). A two-item version of this measure proved a valid and sensitive measure to assess life satisfaction (35). Furthermore, asking about pre-stroke life satisfaction at each measurement will allow us to detect a possible response shift in satisfaction with life.

\section{Determinants}

According to the ICF model, the factors taken into account as potential determinants can be divided into three components. The first component is health condition, which in the present study covers both the pre-stroke health condition (e.g. comorbidity) and the stroke-related health condition (e.g. type of stroke). The second and third components consist of personal factors (e.g. coping) and environmental factors (e.g. social support), respectively. The measures that will be used to assess these factors are displayed in Table 1 (stroke patient) and Table 2 (partner). The partner factors will be analysed as potential environmental determinants of the outcome of the stroke patients, according to the ICF model, but also as outcome measures for the partners themselves.

Personal factors comprise a large proportion of the potential determinants investigated in this cohort study. We will investigate the influence of proactive coping using the Utrecht Proactive Coping Competence Scale (41); passive coping using the Passive coping scale of the Utrecht Coping List (42); selfefficacy using the General Self-Efficacy Scale (43); neuroticism and extraversion using the Eysenck Personality Questionnaire - Revised Short Scale (44); optimism using the Life Orientation Test (45); and appraisals of one's condition using the Illness Cognition Questionnaire (46).

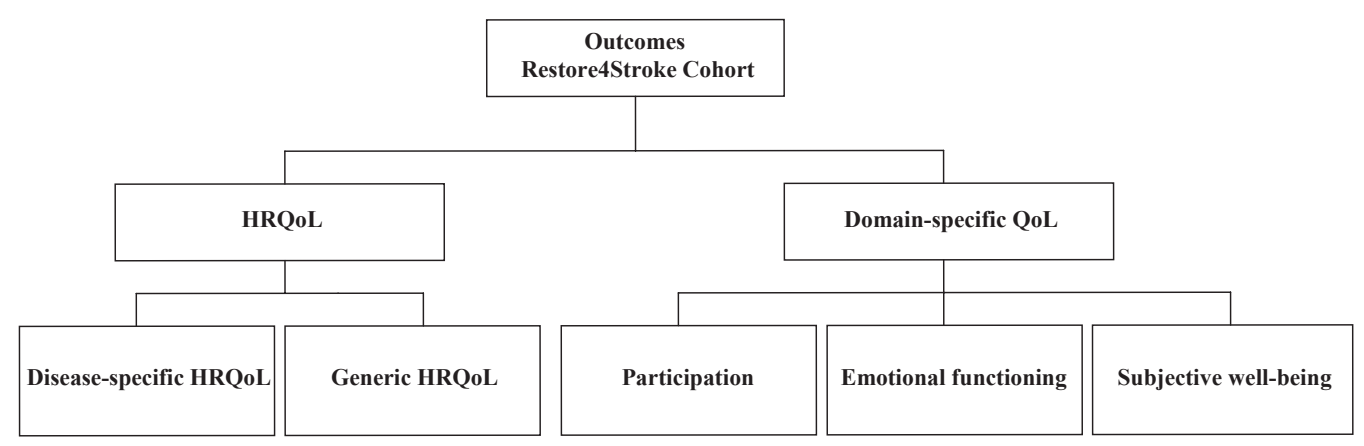

Fig. 1 Outcomes of Restore4Stroke Cohort. HRQoL, health-related quality of life; QoL, quality of life. 
Table 1 Overview of all measurement instruments for the stroke patients and the times of administration

\begin{tabular}{|c|c|c|c|c|c|c|}
\hline & Instrument & $\begin{array}{l}0 \\
\text { months }\end{array}$ & $\begin{array}{l}2 \\
\text { months }\end{array}$ & $\begin{array}{l}6 \\
\text { months }\end{array}$ & $\begin{array}{l}1 \\
\text { year }\end{array}$ & $\begin{array}{l}2 \\
\text { years }\end{array}$ \\
\hline \multicolumn{7}{|l|}{ Outcomes } \\
\hline \multicolumn{7}{|l|}{ HRQoL } \\
\hline Disease-specific HRQoL & Stroke Specific Quality of Life Scale-12 (31) & & $x$ & $x$ & $x$ & $x$ \\
\hline Generic HRQoL & Six-Dimensional EuroQoL (32) & & $x$ & $x$ & $x$ & $x$ \\
\hline \multicolumn{7}{|l|}{ QoL domains } \\
\hline Participation & Utrecht Scale for Evaluation of Rehabilitation - Participation (33) & & $x$ & $x$ & $x$ & $x$ \\
\hline Emotional functioning & Hospital Anxiety and Depression Scale (34) & & $x$ & $x$ & $x$ & $x$ \\
\hline Subjective well-being & Three life satisfaction questions (35) & & $x$ & $x$ & $x$ & $x$ \\
\hline \multicolumn{7}{|l|}{ Determinants } \\
\hline \multicolumn{7}{|l|}{ Pre-stroke health condition } \\
\hline Emotional functioning & $\begin{array}{l}\text { Premorbid question of the Depression scale of the Hospital } \\
\text { Anxiety and Depression Scale (36) }\end{array}$ & $x$ & & & & \\
\hline Participation & $\begin{array}{l}\text { Premorbid frequency scale of the Utrecht Scale for Evaluation } \\
\text { Rehabilitation-Participation (33) }\end{array}$ & $x$ & & & & \\
\hline Comorbidity & Cumulative IIIness Rating Scale (37) & & $x$ & & & \\
\hline \multicolumn{7}{|c|}{ Stroke-related health condition } \\
\hline Stroke characteristics & Type; hemisphere; National Institutes of Health Stroke Scale (29) & $x$ & & & & \\
\hline Motor impairment & $\begin{array}{l}\text { Items } 5 a b \text { and } 6 a b \text { of the National Institutes of Health Stroke } \\
\text { Scale (29) }\end{array}$ & & $x$ & $x$ & & \\
\hline \multirow[t]{2}{*}{$A D L$} & Barthel Index (26) & $x$ & $x$ & $x$ & & \\
\hline & Modified Rankin Scale (38) & & & $x$ & & \\
\hline \multicolumn{7}{|l|}{ Cognition } \\
\hline Impairment & Montreal Cognitive Assessment (39) & & $x$ & $x$ & & \\
\hline Complaints & $\begin{array}{l}\text { Checklist for Cognitive and Emotional Consequences following } \\
\text { stroke (40) }\end{array}$ & & $x$ & $x$ & & \\
\hline Communication & Item 9 of the National Institutes of Health Stroke Scale (29) & & $x$ & $x$ & & \\
\hline \multicolumn{7}{|l|}{ Personal factors } \\
\hline Demographic factors & Age, gender, education, marital status, ethnicity, work status & $x$ & & & & \\
\hline \multicolumn{7}{|l|}{ Psychological factors } \\
\hline Proactive coping & Utrecht Proactive Coping Competence Scale (41) & & $x$ & & & $x$ \\
\hline Passive coping & Passive coping scale of the Utrecht Coping List (42) & & $x$ & & & $x$ \\
\hline Self-efficacy & General Self-Efficacy Scale (43) & & $x$ & & & $x$ \\
\hline Neuroticism & Eysenck Personality Questionnaire - Neuroticism (44) & & $x$ & & & $x$ \\
\hline Extraversion & Eysenck Personality Questionnaire - Extraversion (44) & & $x$ & & & $x$ \\
\hline Optimism & Life Orientation Test (45) & & $x$ & & & $x$ \\
\hline Illness cognitions & Illness Cognition Questionnaire (46) & & $x$ & & & $x$ \\
\hline Care received & Cost Questionnaire & & $x$ & $x$ & $x$ & $x$ \\
\hline
\end{tabular}

The first assessment takes place in the first week post-stroke. The follow-up assessments take place at two months, six months, 1 year, and 2 years post-stroke. HRQoL, health-related quality of life; QoL, quality of life.

The influence of partner personal factors will be investigated using the Utrecht Proactive Coping Competence Scale (41) and the General Self-Efficacy Scale (43).

In addition, a cost questionnaire on use of medical care, home care and support, and medication is administered during assessments T2 until T5. This questionnaire is part of the economic evaluation study, €-Restore4Stroke.

\section{Statistical analyses}

We will first use descriptive statistics. Next, multilevel analyses will be performed to estimate differences between assessments (T2-T5). Multilevel analysis allows for correction for differences between study centres and inclusion of persons with partly missing data in the analyses so that all available data can be used.

After that, latent class growth mixture modelling will be used to investigate if there are different trajectories of QoL between two months and two years after stroke and whether different trajectories can be distinguished.

Prediction of QoL problems on T4 and T5 will be analysed using multivariate regression models. It is hypothesized that lower QoL, at one- and two years after stroke, can reliably be predicted at T2 (two months after stroke), and that QoL after stroke is associated with personal factors and caregiver variables, controlled for pre-stroke health condition and strokerelated health condition. All analyses will be done for the patients and partners separately. Effects with a $P$ value below $0 \cdot 05$ (two-tailed) will be regarded as significant. 
Table 2 Overview of all measurement instruments for the partners and times of administration

\begin{tabular}{|c|c|c|c|c|c|c|}
\hline & Instrument & 0 months & 2 months & 6 months & 1 year & 2 years \\
\hline \multicolumn{7}{|l|}{ Outcomes } \\
\hline \multicolumn{7}{|l|}{ HRQoL } \\
\hline Generic HRQoL & Six-Dimensional EuroQoL (32) & & $x$ & $x$ & $x$ & $x$ \\
\hline \multicolumn{7}{|l|}{ QoL domains } \\
\hline Participation & $\begin{array}{l}\text { Utrecht Scale for Evaluation of Rehabilitation - } \\
\text { Participation (33) }\end{array}$ & $\begin{array}{l}\text { X (only } \\
\text { scale 1) }\end{array}$ & $x$ & $x$ & $x$ & $x$ \\
\hline Emotional functioning & Hospital Anxiety and Depression Scale (34) & & $x$ & $x$ & $x$ & $x$ \\
\hline Subjective well-being & Three life satisfaction questions (35) & & $x$ & $x$ & $x$ & $x$ \\
\hline \multicolumn{7}{|l|}{ Determinants } \\
\hline \multicolumn{7}{|l|}{ Health condition } \\
\hline Burden & Caregiver Strain Index Expanded (47) & & $x$ & $x$ & $x$ & $x$ \\
\hline \multicolumn{7}{|l|}{ Personal factors } \\
\hline Demographic factors & Age, gender, education, ethnicity, work status & $x$ & & & & \\
\hline Proactive coping & Utrecht Proactive Coping Competence Scale (41) & & $x$ & & & $x$ \\
\hline Self-efficacy & General Self-Efficacy Scale (43) & & $x$ & & & $x$ \\
\hline \multicolumn{7}{|l|}{ Environmental factor } \\
\hline Social support & Social Support List (48) & $x$ & $x$ & $x$ & $x$ & $x$ \\
\hline
\end{tabular}

\section{Study organization and funding}

Restore4Stroke is funded by the VSB foundation and Dutch Heart Foundation, and coordinated by ZonMw (Dutch Organization for Health Research and Development).

\section{Summary and conclusions}

The Restore4stroke Cohort study investigates the changes in the QoL of stroke patients and their partners over time, and determines factors predicting QoL, especially the influence of personal and environmental factors.

There are several reasons why this cohort study is innovative. The first is its focus on the changes in QoL after stroke over time (in terms of disease-specific HRQoL, generic HRQoL, participation, emotional functioning, and subjective well-being). Traditionally, much research and rehabilitation care has focused on the physical and functional impact of a stroke (3-5). In addition, this study focuses on the long term, namely two years after stroke instead of the more common follow-up of one year after stroke.

Second, the present study extensively investigates the influence of personal factors on psychosocial functioning. Recent research has suggested the influence of coping on QoL (9). However, there are still several personal factors that have not been evaluated for their possible influence on longterm QoL in stroke patients, although their influence has been proven in other conditions. Examples are perceived locus of control and hope in spinal cord injury (52). That is why personal factors comprise a large proportion of the potential determinants investigated in this study. Moreover, possible changes in personal factors over time can be examined.
Third, the perspective of this study is family-centred. Not much research has been done into the reciprocal relationship between stroke patients and their families, especially their partners (53). The present study therefore examines the influence of partners on the QoL of patients and vice versa.

Lastly, the factors that are investigated are a mixture of medical, paramedical, neuropsychological, and psychological factors, whereas theories and models are usually developed from a specific perspective, for example a medical perspective. However, as illustrated by the ICF model, it is necessary to better understand the relationships and interplay between all components of the model. This can be accomplished by means of trans-disciplinary theories and models that are able to link the various perspectives (54). We hope that the results of Restore4Stroke will provide a starting point for this.

A limitation of this study is that, although we use limited exclusion criteria, the most serious affected patients are excluded, because these patients may not be able to give their consent in the first week post-stroke. This might jeopardize the generalizability of the results to all stroke patients. Furthermore, the outcome, QoL, is only measured with selfassessment questionnaires. However, we do not consider this a problem, because QoL is a subjective concept as defined by the World Health Organization Quality of Life group as individuals' perception of their position in life in the context of the culture and value systems in which they live and in relation to their goals, expectations standards, and concerns' (p. 153) (55).

In conclusion, the information which will be gathered in the present study, especially about the influence of personal and environmental factors on QoL, will be used to establish better rehabilitation care and to develop new interventions for stroke patients and their partners. This should allow stroke patients 
and their partners to make optimal use of their capacity to recover from this common, serious, and disabling condition.

\section{Authors' contributions}

J.V., C.H., and M.P. developed the idea and procured funding for the study. All authors contributed to the design and the protocol of the study. All authors reviewed the manuscript and approved the final version.

\section{References}

1 Vaartjes I, Reitsma JB, de Bruin A et al. Nationwide incidence of first stroke and TIA in the Netherlands. Eur J Neurol 2008; 15: 1315-23.

2 Bach J, Riedel O, Pieper L, Klotsche J, Dodel R, Wittchen H. Healthrelated quality of life in patients with a history of myocardial infarction and stroke. Cerebrovasc Dis 2011; 31:68-76.

3 Teoh V, Sims J, Milgrom J. Psychosocial predictors of quality of life in a sample of community-dwelling stroke survivors: a longitudinal study. Top Stroke Rehabil 2009; 16:157-66.

4 Carod-Artal J, Egido JA, González JL, de Seijas EV. Quality of life among stroke survivors evaluated 1 year after stroke: experience of a stroke unit. Stroke 2000; 31:2995-3000.

5 Carod-Artal FJ, Egido JA. Quality of life after stroke: the importance of a good recovery. Cerebrovasc Dis 2009; 27(Suppl. 1):204-14.

6 Algurén B, Fridlund B, Cieza A, Sunnerhagen KS, Christensson L. Factors associated with health-related quality of life after stroke: a 1-year prospective cohort study. Neurorehabil Neural Repair 2012; 26(3):266-74.

7 Hommel M, Trabucco-Miguel S, Joray S, Naegele B, Gonnet N, Jaillard A. Social dysfunctioning after mild to moderate first-ever stroke at vocational age. J Neurol Neurosurg Psychiatry 2009; 80:371-5.

8 Donnellan C, Hevey D, Hickey A, O'Neill D. Defining and quantifying coping strategies after stroke: a review. J Neurol Neurosurg Psychiatry 2006; 77:1208-18

9 Darlington AS, Dippel DWJ, Ribbers GM, van Balen R, Passchier J, Busschbach JJV. Coping strategies as determinants of quality of life in stroke patients: a longitudinal study. Cerebrovasc Dis 2007; 23:401-7.

10 Ostwald SK, Godwin KM, Cron SG. Predictors of life satisfaction in stroke survivors and spousal caregivers twelve to twenty-four months post discharge from inpatient rehabilitation. Rehabil Nurs 2009; 34:160-74.

11 Bergersen H, Frøslie KF, Sunnerhagen KS, Schanke A. Anxiety, depression, and psychological well-being 2 to 5 years poststroke. J Stroke Cerebrovasc Dis 2010; 19:364-9.

12 Van Exel J, Koopmanschap MA, Wijngaarden JDH, Scholte op Reimer WJM. Costs of stroke and stroke services: determinants of patient costs and a comparison of costs of regular care and care organised in stroke services. Cost Eff Resour Alloc 2003; 1:1-11.

13 Van Exel NJA, Koopmanschap MA, van den Berg B, Brouwer WBF, van den Bos GAM. Burden of informal care giving for stroke patients: identification of partners at risk of adverse health effects. Cerebrovasc Dis 2005; 19:11-7.

14 Van Exel NJA, Scholte op Reimer WJM, Brouwer WBF, van den Berg B, Koopmanschap MA, van den Bos GAM. Instruments for assessing the burden of informal caregiving for stroke patients in clinical practice: a comparison of CSI, CRA, SCQ and self-rated burden. Clin Rehabil 2004; 18:203-14.

15 Scholte op Reimer WJM, de Haan RJ, Rijnders PT, Limbrug M, van den Bos GAM. The burden of caregiving in partners of long-term stroke survivors. Stroke 1998; 29:1605-11.
16 Bugge C, Alexander H, Hagen S. Stroke patients' informal caregivers: patient, caregiver, and service factors that affect caregiver strain. Stroke 1999; 30: 1517-23.

17 Kerr SM, Smith LN. Stroke: an exploration of the experience of informal caregiving. Clin Rehabil 2001; 15:428-36.

18 Rigby H, Gubitz G, Philips S. A systematic review of caregiver burden following stroke. Int J Stroke 2009; 4:285-92.

19 Brouwer WBF, van Exel NJA, van den Berg B, van den Bos GAM, Koopmanschap MA. Process utility from providing informal care: the benefit of caring. Health Policy 2005; 74:85-99.

20 Visser-Meily A, Post M, Schepers V, Lindeman E. Spouses' quality of life 1 year after stroke: prediction at the start of clinical rehabilitation. Cerebrovasc Dis 2005; 20:443-8.

21 Han B, Haley WE. Family caregiving for patients with stroke: review and analysis. Stroke 1999; 30:1478-85.

22 Visser-Meily A, Post M, van de Port I, Maas C, Forstberg G, Lindeman E. Psychosocial functioning of spouses of patients with stroke from initial inpatient rehabilitation to 3 years post-stroke: course and relations with coping strategies. Stroke 2009; 40:1399-404.

23 Achten D, Visser-Meily JMA, Post MWM, Schepers VPM. Life satisfaction of couples three years after stroke. Disabil Rehabil 2012; 34(17):1468-72.

24 World Health Organization. International Classification of Functioning, Disability and Health: ICF. Geneva, World Health Organization, 2002.

25 Visser-Meily JM, Post MW, Schepers VP, Ketelaar M, van Heugten CM, Lindeman E. Spouses' satisfaction with caregiver support in stroke rehabilitation. Scand J Caring Sci 2005; 19:310-6.

26 Collin C, Wade DT, Davies S, Horne V. The Barthel ADL index: a reliability study. Int Disabil Stud 1988; 10:61-3.

27 Meijer R, van Limbeek J, de Haan R. Development of the stroke-unit discharge guideline. Choice of assessment instruments for prediction in the subacute phase post-stroke. Int J Rehabil Res. 2006; 29:1-8.

28 Fleurke AM, Goossen WTF, Hoijtink EJ, Van der Kooij J, Vlastuin M. 2004. Communicatieniveau. Available at [URL]:http://www. zorginformatiemodel.nl/1_documentatie/Doc_Obs_ Communicatieniveau_R01_V1.1.pdf.

29 Brott T, Adams HP, Olinger CP et al. Measurements of acute cerebral infarction: a clinical examination scale. Stroke 1989; 20:864-70.

30 Ritter P, Lorig K, Laurent D, Matthews K. Internet versus mailed questionnaires: a randomized comparison. J Med Internet Res 2004; 6:e29.

31 Post MWM, Boosman H, van Zandvoort MM, Passier PECA, Rinkel GJE, Visser-Meily JMA. Development and validation of a short version of the Stroke-Specific Quality of Life Scale. J Neurol Neurosurg Psychiatry 2010; 83:283-6.

32 Krabbe PFM, Stouthard MEA, Essink-Bot ML, Bonsel GJ. The effect of adding a cognitive dimension to the EuroQol Multiattribute HealthStatus Classification System. J Clin Epidemiol 1999; 52:293-301.

33 Van der Zee CH, Priesterbach AR, Van der Dussen L et al. Reproducibility of three self-report participation measures: the ICF Measure of Participation and Activities Screener, the Participation Scale, and the Utrecht Scale for Evaluation of Rehabilitation-Participation. J Rehabil Med 2010; 42:752-7.

34 Spinhoven PH, Ormel J, Sloekers PPA, Kempen GIJM, Speckens AEM, van Hemert AD. A validation study of the hospital anxiety and depression scale (HADS) in different groups of Dutch subjects. Psychol Med 1997; 27:363-70.

35 Van Koppenhagen CF, Post MW, van der Woude LH et al. Recovery of life satisfaction in persons with spinal cord injury during inpatient rehabilitation. Am J Phys Med Rehabil 2009; 88:887-95.

36 Snaith RP, Zigmond AS. The Hospital Anxiety and Depression Scale Manual. Windsor, NFER Nelson, 1994.

37 Linn BS, Linn MW, Gurel L. Cumulative Illness Rating Scale. J Am Geriatr Soc 1968; 16:622-6. 
38 Van Swieten JC, Koudstaal PJ, Visser MC, Schouten HJ, van Gijn J. Interobserver agreement for the assessment of handicap in stroke patients. Stroke 1988; 19:604-7.

39 Nasreddine ZS, Phillips NA, Bédirian V et al. The Montreal cognitive assessment, MoCA: a brief screening tool for mild cognitive impairment. J Am Geriatr Soc 2005; 53:695-9.

40 Van Heugten C, Rasquin S, Winkens I, Beusmans G, Verhey F. Checklist for cognitive and emotional consequences following stroke (clce-24): development and initial validation. Clin Neurol Neurosurg 2007; 109:257-62.

41 Bode C, Thoolen B, de Ridder D. Het meten van proactieve copingvaardigheden: psychometrische eigenschappen van de Utrechtse Proactieve Coping Competentie lijst (UPCC). Psychol Gezond 2008; 36:81-91.

42 Schreurs PJG, van de Willige G, Brosschot JF, Tellegen B, Graus GMH. De Utrechtse Coping Lijst: UCL. Omgaan Met Problemen En Gebeurtenissen (Herziene Handleiding). Lisse, Swets en Zeitlinger, 1993.

43 Bosscher RJ, Smit JH. Confirmatory factor analysis of the General Self-Efficacy Scale. Behav Res Ther 1998; 36:339-43.

44 Sanderman R, Arrindell WA, Ranchor AV, Eysenck HJ, Eysenck SBG. Het Meten Van Persoonlijkheidskenmerken Met De Eysenck Personality Questionnaire (EPQ): Een Handleiding. Groningen, Noordelijk Centrum voor Gezondsheidsvraagstukken, 1995.

45 Vassar B, Bradley G. A reliability generalization study of coefficient alpha for the life orientation test. J Pers Assess 2010; 92:362-70.

46 Evers AWM, Kraaimaat FW, van Lankveld W, Jongen PJH, Jacobs JWG, Bijlsma WJ. Beyond unfavorable thinking: the illness cognition questionnaire for chronic diseases. J Consult Clin Psychol 2001; 69: $1026-36$
47 Al-Janabi H, Frew E, Brouwer W, Rappange D, van Exel J. The inclusion of positive aspects of caring in the caregiver strain index: tests of feasibility and validity. Int J Nurs Stud 2010; 47:984-93.

48 Kempen GIJM, van Eijk LM. The psychometric properties of the SSL 12-I, A short scale for measuring social support in the elderly. Soc Indic Res 1995; 35:303-12.

49 Post MWM, van der Zee CH, Hennink J, Schafrat CG, Visser-Meily JMA, Berdenis van Berlekom S. Validity of the Utrecht scale for evaluation of rehabilitation-participation. Submitted for publication. Disabil Rehabil 2012; 34(6):478-85.

50 Van der Zee CH, Kap A, Rambaran Mishre R, Schouten EJ, Post MWM. Responsiveness of four participation measures for outcomes of outpatient rehabilitation. J Rehabil Med 2011; 43:1003-9.

51 De Wit L, Putman K, Baert I et al. Anxiety and depression in the first six months after stroke. A longitudinal multicentre study. Disabil Rehabil 2008; 30:1858-66.

52 Van Leeuwen CM, Post MW. Psychosocial issues in spinal cord injury: a review. Spinal Cord 2012; 50:174-87.

53 Carlsson GE, Forsberg-Wärleby G, Möller A, Blomstrand C. Comparison of life satisfaction within couples one year after a partner's stroke. J Rehabil Med 2007; 39:219-24.

54 Stucki G, Reinhardt JD, Grimby G. Organizing human functioning and rehabilitation research into distinct scientific fields. Part II: conceptual descriptions and domains for research. J Rehabil Med 2007; 39:299-307.

55 WHOQOL group. Study protocol for the World Health Organization project to develop a Quality of Life assessment instrument (WHOQOL). Qual Life Res 1993; 2:153-9. 